\title{
EFL Prospective Teacher Educators' Beliefs towards the Use of WhatsApp in English Learning and Teaching
}

\author{
Jepri Ali Saiful* \\ Muhammadiyah University of Surabaya, Jl. Sutorejo No. 59, Surabaya, East Java, Indonesia
}

\begin{abstract}
A B S T R A C T
This study was aimed to investigate the beliefs of EFL prospective teacher educators towards the use of WhatsApp in English learning and teaching. This study used survey research design and the samples were 44 master students of Applied Linguistics Department who had academic degree of B.Ed in TEFL in one of state universities in Yogyakarta. This study found that EFL prospective teacher educators had favorable beliefs towards WhatsApp integration in English learning and teaching. They perceived true that the use of WhatsApp was sine qua non of increasing the learners' English learning proficiency, motivation, autonomy, and language attitude and creating fun and enjoyable English learning atmosphere. Consequently, present English teachers should integrate WhatsApp smartphone application in English learning and teaching.
\end{abstract}

A R T I C L E I N F O

\begin{tabular}{l}
\hline Paper type: \\
Research Article \\
Article history: \\
Received: 10 October 2018 \\
Revised: 16 November 2018 \\
Accepted: 16 November 2018 \\
Keywords: \\
- Beliefs \\
- WhatsApp \\
- English Language Teaching \\
(ELT) \\
- Language Learning
\end{tabular}

Paper type:

Article history:

Received: 10 October 2018

Revised: 16 November 2018

(2018

- Beliefs

- WhatsApp

Language Learning

\section{Introduction}

The trajectory of researches on teacher has pondered on the role of cognitive approach of social psychology, personal beliefs. A unified shelter of inquiry, "teachers' beliefs", has therefore emerged and expounded the teachers' beliefs as the beliefs of teachers about their work, students, subject matter, roles and responsibilities (Pajares, 1992). Hitherto, substantial scholarship has proved to show that the teachers' beliefs are the cornerstone for the success of instructional activities (see for example the studies of Borg \& Al-Busaidi (2012); Hermagustiana et al. (2017); Macalister (2012)). In that sense, the teachers' beliefs are the antecedent of teachers' behaviors or decisions in the classroom. They determine how teacher organize and define the tasks and problems in teaching practices (Xu, 2012). Thus, undoubtedly, understanding teachers' beliefs is magnitude as it is an avenue to reveal the readiness and attitude of teachers to construct lesson plan and identify learning problems. Importantly, in language learning, the teachers' beliefs, particularly about instructional activities, are also a catalyst to apprehend the attempts of students to succeed in target language (Rifkin, 2000). Nevertheless, despite the significant benefits of teachers' beliefs in education and language learning, attempts to investigate the teachers' beliefs are scarce especially in the context of English as a Foreign Language (henceforth EFL) prospective teacher educators in the use of WhatsApp smartphone application in English language learning and teaching.

This avowal is based upon emerging empirical grounds pertaining a research merely on the potential implications and impacts of WhatsApp in English language teaching and learning. For instance, a study of Awada (2016) scrutinized the effectiveness of WhatsApp in improving English learners' critical writing

\footnotetext{
*E-mail Addresses: jepriali1@gmail.com. 
proficiency and perceptions towards learning of English. Similarly, a present study of Hamad (2017) investigates the impacts of WhatsApp in developing students' learning of English. In addition, other studies delve into the roles of WhatsApp in English vocabulary teaching (see Jafari \& Chalak, 2016) and students' perception on a WhatsApp learning tool in EFL classroom (see Mistar \& Embi, 2016). Thus, in a nutshell, the current bodies of study have not yet researched the beliefs of EFL prospective teacher educators towards the use of WhatsApp in English teaching and learning. Ergo magnitude information on the propositions or judgments hold true by EFL prospective teacher educators towards the use of WhatsApp in ELT remains unnoticed and unscrutinized.

Above all, there has been a lack of knowledge on the extent to which EFL prospective teacher educators perceive the importance of WhatsApp integration in English language learning and teaching. To address this emerging gap, the overarching goal of this study is to appraise the beliefs of EFL prospective teacher educators towards the use of WhatsApp in English language learning and teaching. The research questions are thereby formulated as follows: (1) What is EFL prospective teacher educators' general nature of beliefs towards the use of WhatsApp in English language learning and teaching? (2) What are EFL prospective teacher educators' specific beliefs towards the use of WhatsApp in English language learning and teaching in the following aspects: (a) Developing Learners' English language skills and systems (b) English language learning and teaching (c) Learners' language attitude, motivation, and autonomy in learning English (d) English learning atmosphere.

Considering that the focus of this study is to devise the beliefs of EFL teacher educator candidates in the use of WhatsApp in English learning and teaching, this study therefore needs to define the operational of key terms. The teachers' beliefs of this study refer to the verbal statements of proposition or judgment perceived true by the EFL prospective teacher educators towards the importance and potential use of WhatsApp in English language learning and teaching. This delimitation is derived from a theoretical construct of teachers' beliefs as suggested by Borg (2015). Borg (2015) suggests that the review of literature on the teachers' beliefs should lie on Pajares' (1992) works as they are comprehensive and helpful. Pajares (1992) elucidates that teachers' beliefs relate to the beliefs of teachers about their work, students, subject matter, roles, and responsibilities. Thus, in the light of the Pajares' view, the teachers' beliefs of this study are narrowed down only to the area of subject matter, i.e. the teaching and learning of English using WhatsApp. In addition, regards of the nature of belief per se, this study refer to Borg's (2001) definition of belief. Borg (2001) posits that beliefs are germane with the proposition or judgment hold true by individuals and therefore inflame commitment. Hence, the beliefs of the teachers of this study relate to verbal statements of proposition or judgment perceived true by the teachers.

\section{Research Method}

\subsection{General Background of Research}

This study used a survey research design and was conducted in Applied Linguistics Department in one of Graduate Schools of State University in Indonesia. The applied linguistics department was chosen due its quality of producing professional graduates of M.Ed in Foreign Language Education as proven by the national accreditation of the department, "A". Therefore, the samples of this study had solid legitimation of knowledge on current foreign language learning and teaching practices. Consequently, their responses towards present integration of mobile application, WhatsApp, in foreign language learning would be representative for other English/foreign language teacher educators in general. Importantly, the department had already required the students to have WhatsApp account for the communication purposes among the students and faculties. As a result, the students were used to use WhatsApp smartphone application and therefore they could make valid and reliable judgment on WhatsApp integration in English teaching and learning.

\subsection{Sample of Research}

The population was all master students of Applied Linguistics Department who had academic degree of B.Ed in TEFL. The samples were 44 students who were taken randomly from the population. The samples consisted of 14 males and 30 females. Importantly, the samples were using WhatsApp Smartphone Application as their major daily communication tool. 


\subsection{Instrument and Procedures}

A questionnaire on beliefs of WhatsApp integration in English learning and teaching was used as an instrument in this study. The instrument was designed based upon theoretical constructs of WhatsApp implications for English teaching and learning practices. There were four aspects of the implications in the questionnaire as follows: (a) Developing Learners' English language skills and systems (5 items), (b) English language learning and teaching (6 items), (c) Learners' language attitude, motivation, and autonomy in learning English (3 items), (d) English learning atmosphere (1 items).

The total of items in the questionnaire was 15 and all the items were positive. Furthermore, the statements in the items were put in four-point Likert scale, $4=$ strongly agree, $3=$ agree, $2=$ disagree, and $1=$ strongly disagree. This four-point scale was used to get more precise responses of the beliefs of the samples towards the use of WhatsApp in English learning and teaching. Afterwards, the constructed instrument was tested its validity and reliability. The instrument was tried out to 30 respondents who were from graduate school of Applied Linguistics department from other state university in Indonesia.

The result of validity test using Pearson Correlation revealed that all 15 items got a score of Correlated Item Total Correlation above 0.300 . This indicated that the instrument of this study was valid. Besides, the reliability test using Alpha Cronbach showed that the instrument was reliable proven by a score of Alpha index above $0.700,0.882$. Above all, the instrument of this study was valid and reliable to get data on the beliefs of EFL prospective teacher educators' beliefs towards the use of WhatsApp in English learning and teaching.

\subsection{Data Analysis}

The data analysis of this study was in the form of descriptive statistics. The descriptive statistics was used to obtain the general responses of the samples towards all items of the questionnaire. In other words, descriptive statistics was to reveal the general nature of beliefs of EFL prospective teacher educators towards the integration of WhatsApp in English learning and teaching. Likewise, descriptive statistics was also performed to get specific responses of the samples towards the four aspects of WhatsApp integration in English learning and teaching in the questionnaire.

\section{Result and Discussion}

\subsection{Results}

\subsubsection{General Nature of Beliefs towards the Use of WhatsApp in English Learning and Teaching}

The following was the result of general beliefs towards WhatsApp integration.

Table 1. Descriptive Statistics of General Beliefs towards the Use of WhatsApp in English Learning and Teaching

\begin{tabular}{lcccc}
\hline & $\mathrm{N}$ & Mean $^{\mathrm{a}}$ & Std. Deviation & Std. Error Mean \\
\hline Beliefs & 44 & 45.9773 & 6.59277 & .99390 \\
\hline a. Mean score & $15-16.25=$ "very unfavorable"; $26.26-37.5$ "unfavorable"; & \\
& $37.6-48.75=$ = "favorable" $; 48.76-60=$ "very favorable"; &
\end{tabular}

Table 1 showed that the mean score was in the "favorable" category of belief, 45.9773. This indicated that the samples, EFL prospective teacher educators, had favorable belief towards the use of WhatsApp in English learning and teaching. In addition, for the detail distribution of responses from each category of beliefs, Diagram 1 was presented. 


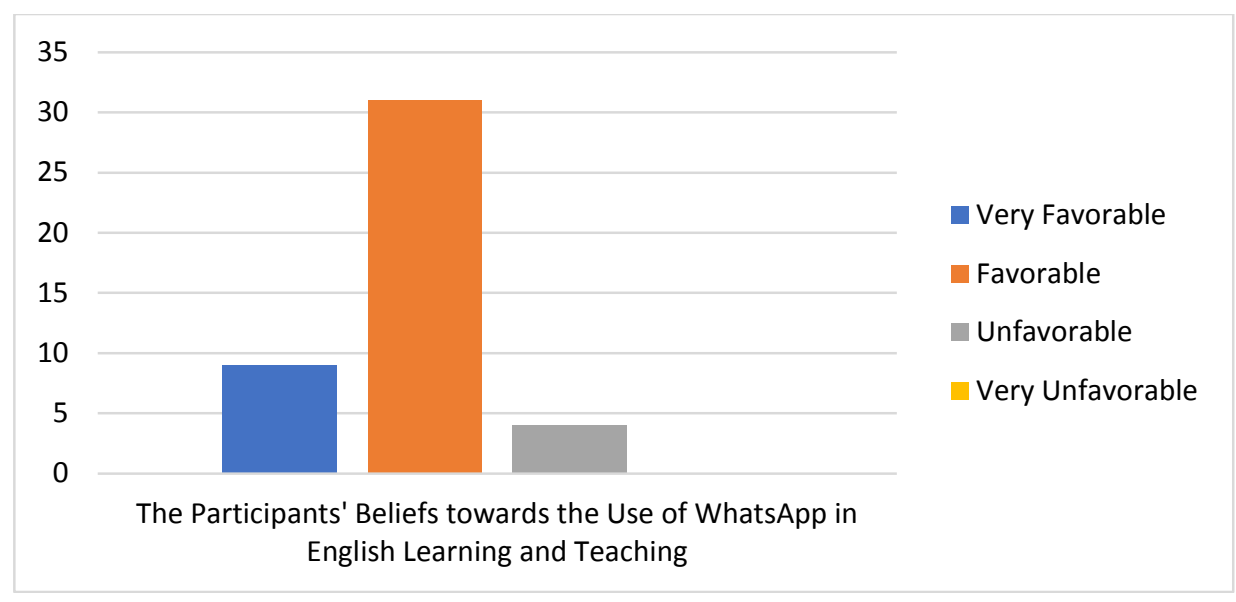

Diagram 1. Distribution of Beliefs of EFL Prospective Teacher Educators towards the Use of WhatsApp in English Learning and Teaching

Diagram 1 revealed that there were nine samples who had "very favorable" beliefs, 31 samples who had "favorable" beliefs, four samples who had "unfavorable" beliefs, and none who had "very unfavorable" beliefs towards the use of WhatsApp in English Learning and Teaching. In that sense, the diagram 1 showed that the majority of the samples, EFL prospective teacher educators, had "favorable" beliefs towards the use of WhatsApp in English learning and teaching, although still there were few who had "unfavorable" belief.

\subsubsection{Specific of Beliefs towards the Use of WhatsApp in English Learning and Teaching}

The result of specific beliefs towards the use of WhatsApp in English learning and teaching was presented in Table 2.

Table 2. Descriptive Statistics of Specific Beliefs towards the Use of WhatsApp in English Leaning and Teachers

\begin{tabular}{|c|c|c|c|c|}
\hline $\begin{array}{l}\text { Aspects of Beliefs } \\
\text { towards WhatsApp } \\
\text { Integration in } \\
\text { English Learning } \\
\text { and Teaching }\end{array}$ & Statements & $\begin{array}{l}\text { Item } \\
\text { mean } \\
\text { score }\end{array}$ & $\begin{array}{l}\text { Standard } \\
\text { Deviation }\end{array}$ & $\begin{array}{l}\text { Aspects } \\
\text { mean } \\
\text { score }^{b}\end{array}$ \\
\hline \multirow{5}{*}{$\begin{array}{l}\text { Developing } \\
\text { Learners' English } \\
\text { language skills and } \\
\text { systems }\end{array}$} & $\begin{array}{l}\text { I believe that sending audio feature of WhatsApp is an important } \\
\text { tool for enhancing the English listening skill of learners }\left(1^{\mathrm{a}}\right) \text {. }\end{array}$ & 3.0682 & .50106 & \multirow[t]{5}{*}{3.06818} \\
\hline & $\begin{array}{l}\text { Voice notes feature of WhatsApp is a medium of improving and } \\
\text { practicing English pronunciation for learners (2). }\end{array}$ & 3.0909 & .60302 & \\
\hline & $\begin{array}{l}\text { I believe that video call feature of WhatsApp develops the English } \\
\text { speaking or communication skill of learners (3). }\end{array}$ & 2.9545 & .68044 & \\
\hline & $\begin{array}{l}\text { Status feature of WhatsApp facilitates the learners to practice } \\
\text { English writing (4). }\end{array}$ & 2.9773 & .62835 & \\
\hline & $\begin{array}{l}\text { Chat feature of WhatsApp is a magnitude mean of improving } \\
\text { English writing skill of learners (5). }\end{array}$ & 3.2500 & .65147 & \\
\hline \multirow[t]{6}{*}{$\begin{array}{l}\text { English language } \\
\text { learning and } \\
\text { teaching }\end{array}$} & $\begin{array}{l}\text { Group chat feature of WhatsApp is an important medium for English } \\
\text { learning discussions and reflections between teachers and students } \\
\text { (6). }\end{array}$ & 3.4318 & .58658 & \multirow[t]{6}{*}{3.17803} \\
\hline & $\begin{array}{l}\text { I believe that group chat feature of WhatsApp increases the } \\
\text { activeness or participations of learners in learning English (7). }\end{array}$ & 3.2727 & .65994 & \\
\hline & $\begin{array}{l}\text { Document sending is an important feature of WhatsApp for teachers } \\
\text { and learners to propagate and exchange the English learning } \\
\text { materials or references (8). }\end{array}$ & 3.6364 & .48661 & \\
\hline & $\begin{array}{l}\text { I believe that Video call feature of WhatsApp is a magnitude avenue } \\
\text { for English speaking assessment (9). }\end{array}$ & 2.8409 & .74532 & \\
\hline & $\begin{array}{l}\text { Voice Notes is an important feature of WhatsApp to help teachers } \\
\text { give short corrective feedback about the progress of learners' } \\
\text { English learning (10). }\end{array}$ & 3.0455 & .71380 & \\
\hline & $\begin{array}{l}\text { Chat feature of WhatsApp is important as it is a mean for English } \\
\text { writing assessment for teachers (11). }\end{array}$ & 2.8409 & .71343 & \\
\hline
\end{tabular}


Table 2. (Continued)

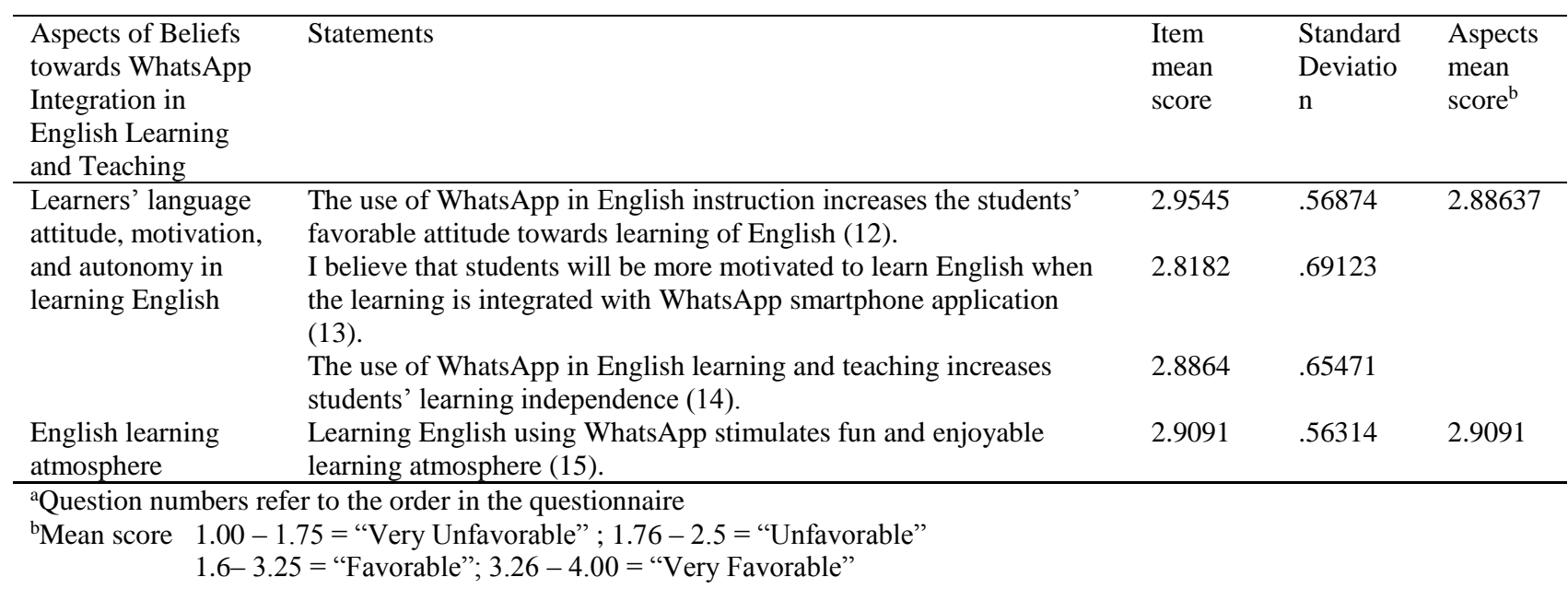

Table 2 demonstrated that the specific beliefs of EFL prospective teacher educators towards the use of WhatsApp in English learning and teaching were "favorable" in four following aspects; developing Learners' English language skills and systems (mean = 3.06818); English language learning and teaching (mean $=$ 3.17803); learners' language attitude, motivation, and autonomy in learning English (mean = 2.88637); and English learning atmosphere (mean $=2.9091)$.

\subsection{Discussion}

The overarching goal of this study is to investigate the beliefs of EFL prospective teacher educators towards the use of WhatsApp in English learning and teaching. The results of descriptive statistics of table 1 and diagram 1 demonstrated that the majority of EFL prospective teacher educators had favorable beliefs towards WhatsApp integration in English learning and teaching. In that sense, in the light of Borg's (2001) view, these results indicate that the EFL prospective teacher educators have positive proposition or judgment towards the potential use of WhatsApp in English learning and teaching. In other words, EFL prospective teacher educators agree to postulate that the use of WhatsApp is beneficial and important for English learning and teaching. This postulate is consistent with the avowal of emerging empirical ground from Ta'amneh (2017) which posits that "English lessons can be learned more effectively through integrating technological applications such as WhatsApp messenger in learning English than the traditional methods" (p.150).

The result of diagram 1 also showed that there were few EFL prospective teacher educators who had unfavorable belief towards WhatsApp integration in English learning and teaching. This negative belief could be due to the shortcomings of the WhatsApp integration in the learning and teaching of English. Hamad (2017) reports that there are few disadvantages of WhatsApp application in English learning such as preparing the learning materials and manages or monitor the group chat of WhatsApp. However, Hamad (2017) further accentuates that despite the few minuses, prolific benefits of WhatsApp application in English learning and teaching still dominate such as developing English skill and enriching the English vocabulary of learners.

Exist to support the significant benefits of WhatsApp implementation in the learning and teaching of English, the result of descriptive statistics of table 2 indicates that EFL prospective teacher educators perceive true that the use of WhatsApp can develop learners' English language skills and systems, have profound implications in English language teaching and learning, increase learners' positive language attitude, motivation, and autonomy in learning English, and build fun and enjoyable English learning atmosphere. This result of table 2 is consistent with present substantial scholarship showing that the use of WhatsApp can amplify the students' motivation in learning English (see Awada, 2016), English proficiency (see Mistar \& Embi, 2016), and English vocabulary learning (see Jafari \& Chalak, 2016). 


\section{Conclusion}

The major highlight of this study contributes to knowledge field of teachers' beliefs and mobile assisted language learning is that this study reveals the nature of beliefs of EFL prospective teacher educators towards the use of WhatsApp in English learning and teaching. This study finds that EFL prospective teacher educators have favorable beliefs towards WhatsApp integration in English learning and teaching. In that sense, this study extends our knowledge that EFL prospective teacher educators have positive judgment or proposition to the implementation of WhatsApp in English teaching and learning. They perceive true that the WhatsApp is beneficial and prominent for English teaching and learning activities. They postulate that WhatsApp can enhance learners' English language skills and systems, provide various implications in English language teaching and learning, increase learners' positive language attitude, motivation, and autonomy in learning English, and build fun and enjoyable English learning atmosphere. Thus, for present EFL teachers and educators, in order to mushroom the mastery of learners in English language, the WhatsApp smartphone application should therefore be integrated in teaching and learning activities.

\section{Acknowledgement}

Jepri Ali Saiful expresses his special thanks to Lembaga Pengelola Dana Pendidikan (LPDP)/ Indonesian Endowment Fund for Education which gives a master degree full scholarship for Mr. Saiful to study in Applied Linguistics Department, Graduate School, Yogyakarta State University, Indonesia.

\section{References}

Awada, G. (2016). Effect of WhatsApp on critique writing proficiency and perceptions toward learning. Cogent Education, VI(1), 1-25. doi:10.1080/2331186X.2016.12

Borg, M. (2001). Teachers' beliefs. ELT Journal, LV(2), 186-188. doi:10.5785/23-2-52

Borg, S. (2015). Teacher cognition and language education: Research and practice. London \& New York: Bloomsbury Academic.

Borg, S., \& Al-Busaidi, S. (2012). Learner autonomy: English language teachers' beliefs and practices. British Council ELT Research Papers, XII(7), 1-45.

Hamad, M. M. (2017). Using WhatsApp to enhance students' learning of English language, "experience to share". Higher Education Studies, VII(4), 74-87. doi:10.5539/hes.v7n4p7

Hermagustiana, I., Hamra, A., Rahman, A. Q., \& Salija, K. (2017). Reflection of teacher cognition in EFL vocabulary instructional practices in Indonesia. International Journal of English Linguistics, VII(5), 34-45.

Jafari, S., \& Chalak, A. (2016). The role of WhatsApp in teaching vocabulary to Iranian EFL learners at junior high school. English Language Teaching, XIX(8), 85-92. doi:10.5539/elt.v9n8p85

Macalister, J. (RELC Journal). Pre-service teacher cognition and vocabulary teaching. 2012, XLIII(1), 99-111. doi: $10.1177 / 0033688212439312$

Mistar, I. b., \& Embi, M. A. (2016). Students' perception on the use of WhatsApp as a learning tool in esl classroom. Journal of Education and Social Sciences, IV, 96-104.

Pajares, M. F. (1992). Teachers' beliefs and educational research: Cleaning up a messy construct. Review of Educational Research, LXII, 307-332. doi:10.3102/00346543062003307

Rifkin, B. (2000). Revisiting beliefs about foreign language learning. Foreign Language Annals, XXXIII(4), 394-408. doi:10.1111/j.1944-9720.2000.tb00621.x

Ta'amneh, M. A. (2017). The Effect of using WhatsApp messenger in learning English language among university students. International Research in Education, V(1), 143-151. doi:10.5296/ire.v5i1.10801

$\mathrm{Xu}, \mathrm{L}$. (2012). The role of teachers' beliefs in the language teaching-learning process. Theory and Practice in Language Studies, II(7), 1397-1402. doi:10.4304/tpls.2.7.1397-1402 